\title{
TEORI KLASIK DAN KONTEMPORER: DARI RATIONAL EMOTIVE BEHAVIORAL THERAPY (REBT) HINGGA COGNITIVE RESTRUCTURING (CR)
}

\author{
Lailul Ilham dan Ach. Farid \\ Pascasarjana UIN Sunan Kalijaga Yogyakarta \\ lailulilham44@gmail.com |djufri91elfarid@gmail.com
}

\begin{abstract}
Sebagaimana sifat ilmu pengetahuan pada umumnya, teknik-teknik layanan konseling juga mengalami pembaharuan berdasarkan kebutuhan dan persoalan-persoalan yang di alami individu, baik dalam aspek psikologis, kognitif, ataupun behavior. Pembaruan tersebut dapat bersifat induktif (menuju cakupan yang lebih luas) atau deduktif (menuju cakupan yang lebih khusus/spesifik). Perubahan-perubahan tersebut merupakan bukti bahwa teknik konseling juga dialektis dan tangap terhadap aspek-aspek permasalahan individu secara mendasar. Sehingga dalam pembahasan teori-teori konseling ini akan diuraikan dua teknik layanan konseling yang secara historisitas keduanya merupakan teknik yang berakar pada teori yang sama dan menalami pembaharuan (deduktif/induktif) berdasarkan perkembangan ilmu pengetahuan dalam kontek ilmu konseling.
\end{abstract}

Kata Kunci: Guidance; School; Madrasah Counseling; Tohirin 


\section{A. Pendahuluan}

Berpikir merupakan ciri khas manusia serta sebagai potensi dasar yang membedakan dengan makhluk lain. Kemudian berpikir juga menjadi landasar utama bagi manusia dalam menentukan pilihan-pilihan tertentu. Manusia memutuskan suatu hal dengan berpikir dan tindakan tersebut merupakan sebagai fungsi atas kognitif yang dimiliki. Manusia tidak hanya menerima rangsangan dari pengalaman inderawi, mengingat peristiwa, dan menghubungkan satu peristiwa dengan peristiwa lain, namun manusia dapat mengalami dan menerima informasi melalui pengalaman serta fungsi kognitifnya. Hal tersebut menjadi sebab beragamnya asumsi mengenai informasi dalam benak manusia, dengan berbagai pertimbangan, proses berpikir dan pengambilan keputusan atas dasar pertimbangan matang.

Sebagaimana Satiadarma mengatakan bahwa terjadinya penyimpangan prilaku manusia karena adanya penyimpangan pada fungsi kognitif. Perbaikan pada prilaku manusia yang mengalami penyimpangan prilaku, terlebih dahulu harus dilakukan perbaikan pada fungsi kognitifnya. Pernyataan ini menunjukkan pentingnya pengaruh aspek kognitif terhadap prilaku manusia. Peran kognitif dalam mempertimbangkan putusan untuk melakukan tindakan tertentu menjadi fokus perhatian dalam pendekatan cognitive behavioral therapy. ${ }^{1}$

Kemudian Teknik Cognitive Restructuring (TCR) merupakan teknik konseling baru yang berakar dari teori-teori kognitif dan behavioral, pada teknik TCR tersebut mengalami pemusatan perhatian dalam orientasi penanganannya yaitu pada aspek kognitif. Kondisi kognitif klien yang dianggap mengalami masalah (irasional) mendapat perhatian utama dalam proses penanganan karena persepsinya prilaku menyimpang sebagai aksi kongkrit dari prilaku menyimpang manusia yang disebabkan oleh kesalahan berfikir. Berangkat dari konsep tersebut melakukan penanganan terhadap aspek kognitif merupakan strategi paling efektif dalam menghindari terjadinya prilaku menyimpang.

${ }^{1}$ A. Kasandra Oemarjoedi, Pendekatan Cognitive Behavior Dalam Terapi (Jakarta: Kreativ Media, 2003), 47. 


\section{B. Teori klasik; Rational Emotive Behavioral Therapy (REBT)}

Teknik Rational Emotif Behavioral Therapy (REBT) merupakan metode konseling yang berdasar pada kognitif, artinya proses layanan penyembuhan terhadap klien dilakukan dengan membenarkan terlebih dahuu kondisi kognitif klien, termasuk pemberian perspektif baru dalam berpikir atau penyusunan ulang cara berpikir. Berdasarkan gambaran tersebut secara konseptual dapat dikatakan bahwa teknik Cognitive Restructuring (CR) sebagai metode layanan konseling yang juga berpusat pada aspek kognitif merupakan pendekatan REBT model baru, sehingga dalam kumpulan perkembangan teknik-teknik konseling diistilahkan sebagai teknik konseling kontemporer.

Berangkat dari asumsi konseptual di atas sehingga dapat diposisikan bahwa REBT merupakan teknik konseling klasik dan teknik CR merupakan teknik kontemporer. Sebab, keduanya merupakan teknik konseling yang memiliki dasar penanganan yang sama (kognitif), namun dalam perkembangannya terjadi penyesuaian, pembaharuan, dan perubahan-perubahan konseptual sehingga teknik tersebut mengalami deduksi atau fokus layanan semakin spesifik yaitu pada aspek kognitif. Pada teknik REBT cakupannya cukup luas sebab meskipun orientasinya pada kognitif namun dalam proses layanan konselor tetap memperhatikan penanganan terhadap kondisi emosional dan behavior klien. Kemudian dalam perkembangan mutakhir muncul teknik baru dan lebih spesifik kepada aspek kognitif yaitu teknik Cognitive Restructuring, teknik tersebut fokus pada pengorganisasian atau penyusunan ulang kerangka berpikir supaya menjadi lebih rasional.

Dalam salah literatur disebutkan bahwa teknik kontemporer Cognitive Restructuring merupakan salah satu dari beberapa teknik yang didasarkan pada pendekatan prilaku dan kognitif, namun dalam pelayanan teknik tersebut lebih spesifik menangani aspek kognitif. Pendekatan prilaku dan kognitif tersebut dalam sejarahnya dimotori tokoh-tokoh psikologi antara lain; Albert ellis, William Glasser, dan Donald Meinchenbaum. ${ }^{2}$

${ }^{2}$ Erford, Bradley T., 40 Teknik yang Harus Diketahui Setiap Konselor (Yogyakara: Pustaka Pelajar, 2015), 256. 
Kemudian sejarah menyebutkan bahwa dalam beberapa dekade semangat menciptakan pendekatan prilaku dan kognitif mengalami penurunan, realitas tersebut disadari oleh para konselor dan para konselor memiliki aumsi kuat bahwa pikiran dan perilaku adalah dua hal berbeda namun kedua sama-sama memiliki potensi perubahan yang efektif. Kemudian muncullah tokoh-tokoh perintis gagasan baru yaitu pendekatan integrasi kognitif-behavioral, kemudian melakukan pengembangan teoriteori konseling yang didasarkan pada kedua pendekatan tersebut.

Berdasarkan sejarah perkembangan teori klasik, Rational Emotive Behavioral Therapy (REBT) diciptakan dan dikembangkan oleh Albert Ellis pada tahun 1995an, ia seorang prikoterapis yang terinspirasi oleh ajaran-ajaran filsuf Asing; Yunani, Romawi, dan ajaran-ajaran modern yang mengarah kepada teori belajar kognitif. Awalnya pendekatan ini disebut Rational Therapy (RT) karena Ellis ingin menekankan aspek rasional dan fitur kognitif. ${ }^{3}$

Kemudian pada tahun 1961, nama Rational Therapy (RT) berubah menjadi Rational Emotive Therapy (RET) untuk menunjukkan bahwa pendekatan tersebut tidak mengabaikan emosi. Kemudian lebih dari 50 tahun keberadaannya, RET telah berhasil diterapkan menjadi layanan untuk perorangan, kelompok, perkawinan, dan terapi keluarga untuk beragam masalah. Lebih dari 30 tahun kemudian (tahun 1993), Ellis mengganti nama pendekatan tersebut menjadi Rational Emotive Behavioral untuk menunjukkan bahwa pendekatan ini tidak mengabaikan aspek prilaku. Kemudian pada tahun 1993, dalam News Latter yang dikeluarkan oleh The Institute Rational Emotive Therapy, Ellis mengumumkan bahwa ia mengganti nama Rational-Behavioral Therapy (RET) menjadi Rational Emotive Behavioral Therapy (REBT). ${ }^{4}$

3 Gantina Komalasari, Eka Wahyuni, Karsih, Teori dan Teknik Konseling (Jakarta: PT. Indeks, 2011), 201.

${ }^{4}$ Nelson-Jones, Theory and Practice of Counseling and Therapy, Terjemahan Helly Prajitno \& Sri Mulyani, 2012, Jakarta: Pustaka Pelajar (Jakarta: Pustaka Pelajar, 2011), 137. 
Teori REBT adalah pendekatan yang menekankan pada pentingnya peran pikiran pada tingkah laku, dan REBT dari Ellis merupakan filsafat irasional yang diekspresikan melalui beberapa tingkah laku dalam bentuk perilaku emosional neurotik. Berdasarkan atas kepercayaan bahwa manusia dapat menyusun kembali pemikiran rasionalnya, yang selanjutnya diikuti dengan pola tingkah laku. ${ }^{5}$ Sebagaimana tokoh pendekatan yang lain (psikoanalisis dan behavioristik, Ellis juga memiliki keyakinan bahwa perilaku dapat dirubah dengan terlebih dahulu merubah cara berpikirnya. Ada beberapa perbedaan mengenai psikologi kognitif dan psikologi behaviorisme, yaitu (Schultz and Schultz 2013, 596):

Pertama, Para psikolog kognitif lebih memfokuskan pada proses-proses memahami ketimbang sekedar merespon stimuli. Faktor yang penting adalah proses dan peristiwa mental, bukan koneksi antara stimulus respon, penekanannya adalah pikiran bukan perilaku. Hal ini bukan berarti para psikolog kognitif mengabaikan perilaku, tetapi respon perilaku bukanlah satu-satunya fokus riset mereka. Respon behavioral adalah sumber untuk membuat dugaan dan mengambil kesimpulan mengenai proses-proses mental yang menyertainya.

Kedua, Psikolog kognitif tertarik pada bagaimana pikiran menyusun pengalaman. Pikiran memberi bentuk dan koherensi kepada pengalaman mental, proses ini adalah pokok kajian psikologi kognitif. Para penerus abad dua puluh, behavioris Skinnerian bersi-keras menyatakan bahwa pikiran tidak memiliki kemampuan untuk mengorganisir yang inheren.

Ketiga, Psikolog kognitif yakin bahwa individu secara aktif dan kreatif mengelola stimuli yang mereka terima dari lingkungan. Dan kita mampu berpartisipasi dalam memperoleh dan mengaplikasikan pengetahuan, dengan sengaja menghadiri suatu acara tertentu dan memilih untuk menyimpannya ke dalam memori. Namun bagi psikolog behaviorisme perilaku diibaratkan kertas kosong, yang menjadi tampat ditulisnya pengalaman inderawi.

${ }^{5}$ Gantina Komalasari, Eka Wahyuni, Karsih, Teori dan Teknik Konseling., 203. 
Sebagai tokoh teori pendekatan REBT, Albert Ellis terus melakukan pengamatan dan usaha-usaha pengembangan sehingga dari awal sampai akhir abad 19 teori REBT mengalami beberapa perubahan antara lain; perubahan pada fokus penanganannya, perubahan nama (dari RT-RET-REBT-CBT), perubahan-perubahan tersebut terus dilakukan atas dasar pengamatan ulang dan usaha memperbaiki pendekatan konseling sampai menemukan metode yang lebih efektif dalam menangani kasus-kasus kognitif dan behavioral individu.

Berdasarkan fakta sejarah ditemukan bahwa perkembangan mutakhir pendekatan REBT adalah Cognitive Behavioral Therapy (CBT), satu pendekatan yang cenderung mengintegrasikan dua aspek yaitu kognitif dan behavioral dalam satu pemahaman utuh. CBT merupakan pendekatan konseling yang dirancang untuk menyelesaikan permasalahan dengan melakukan restrukturasi kognitif dan prilaku yang menyimpang. Pendekatan CBT didasarkan pada formulasi kognitif, keyakinan dan strategi prilaku yang mengganggu. Proses konseling didasarkan pada konseptualisasi atau pemahaman konseli atas keyakinan khusus dan pola prilaku konseli. Tujuan teknik CBT adalah melakukan restrukturasi kognitif yang menyimpang dan sistem kepercayaan, untuk membawa perubahan emosi dan prilaku ke arah yang lebih baik. ${ }^{6}$

Bush mengungkapkan bahwa CBT merupakan perpaduan dari dua pendekatan dalam psikoterapi yaitu Cognitive Therapy dan Behavioral Therapy. Terapi kognitif fokusk pada pikiran, asumsi dan kepercayaan. Terapi kognitif memfasilitasi individu untuk belajar mengenali dan mengubah kesalahan. Terapi kognitif tidak hanya berkaitan dengan positive thingking, tetapi berkaitan pula dengan happy thingking. Sedangkan terapi tingkah laku membantu membangun hubungan antar situasi permasalahan dengan kebiasaan merelaksasi permasalahan.

${ }^{6}$ Beck, Judith S., Cognitive Behavioral Therapy: Basic and Beyond (2nd ed), (translite) (New York: The Guilfard Press, 2011), 67 . 
Individu belajar mengubah prilaku, menenangkan pikiran dan tubuh sehingga merasa lebih baik, berpikir lebih jelas dan membantu membuat keputusan yang tepat. Matson dan Ollendick mendefiniskan CBT sebagai pendekatan dengan sejumlah prosedur yang secara spesifik menggunakan kognisi sebagai bagian utama dalam konseling. Adapun fokus konseling pada persepsi, kepercayaan, dan pikiran. ${ }^{7}$

Berdasarkan interaksi inilah muncul teori baru yaitu terapi behavioral kognitif (Cognitive Behavioral Therapy), pada tahun 1970-an terapi tersebut dikenal dengan istilah modivikasi behavioral kognitif, namun setelah tahun 1990-an dikenal dengan istilah terapi behavioral kognitif. Terapi behavior dan kognitif saling bekerja sama dan komitmen dalam menetapkan kriteria utama penilaian efektifitas penanganan apapun. Generasi ketiga dari behavioral tidak berusaha mengubah kognisi klien secara langsung melainkan berusaha mengubah reaksi klien terhadap kognisi mereka sendiri. ${ }^{8}$

Adapun faktor munculnya pendekatan atau terapi kognitif adalah sebagai reaksi terhadap perkembangan pendekatan perilaku yang cenderung mengingkari peran kognitif dalam perkembangan teknik konseling, kaitannya dengan usahausaha mendorong kemandirian konseli serta mengarahkan pada keadaan hidup yang lebih baik. Kecenderungan mempertahankan konsep terapi (masing-masing) terus dilakukan, dengan tidak berhenti melakukan eksplorasi-eksplorasi terapi menggunakan potensi dasar pendekatan masing-masing, sehingga terus ditemukan persoalan baru serta metode penanganan dan model pendekatan yang juga baru.

7 Jarvis, Matt, Teori-Teori Psikologi: Pendekatan Modern Untuk Memahami Perilaku, Perasaan, Pikirannya Manusia (Bandung: Nusa Media, 2006), 152.

8 Joseph, Gerry Martin and Pear, Modifikasi Prilaku: Makna dan Penerapanya (Yogyakarta: Pustaka Pelajar, 2015), 745. 


\section{Teori kontemporer; Cognitive Restructuring (CR)}

Cognitive Restructuring merupakan teknik model baru yang lahir atau berasal dari konsep terapi kognitif dan dalam berbagai kajian kognitif biasanya dikaitkan dengan karya Albert Ellis, Aaron Beck, dan Donald Maichenbaum. Dalam kajiankajian konseling teknik tersebut biasanya disebut Correcting Cognitive karena melibatkan prinsip-prinsip belajar pada pikiran. Teknik tersebut juga dirancang untuk membantu mencapai respon emosional yang lebih baik dengan mengubah kebiasaan dan penilaian yang sedemikian rupa untuk meminimalisir bias.

Teknik Cognitive Restructuring didasarkan pada dua asumsi: pertama, Pikiran irasional dan kognisi defektif meghasilkan self-defeating behaviors (perilaku disengaja yang memiliki efek negatif pada diri sendiri-psychwiki.com). Kedua, Pikiran dan pernyataan tentang diri sendiri dapat diubah melalui perubahan pandangan dan kognisi personal. Biasanya, konselor profesional menggunakan Cognitive Restructuring dengan konseli yang membutuhkan bantuan untuk mengganti pikiran dan interpretasi negatif dengan pikiran dan tindakan yang lebih positif. ${ }^{9}$

Kemudian dalam implementasi teknik Cognitive Restructuring, Doyle mendeskripsikan sebuah prosedur tujuh langkah spesifik untuk diikuti oleh konselor profesional ketika menerapkan cognitive restructuring, adapun tujuh langkah tersebut antara lain: ${ }^{10}$ a) Kumpulkan informasi latar belakang untuk mengungkapkan bagaimana klien menangani masalah di masa lalu maupun saat ini. b) Bantu klien menjadi sadar pada proses pikiranya. Diskusikan contoh-contoh kehidupan nyata yang mendukung kesimpulan klien dan didiskusikan berbagai interpretasi yang berbeda tentang bukti yang ada. c) Periksa proses berfikir rasional klien, yang hubungannya dengan kesejahteraan klien. Konselor profesional dapat membesarbesarkan pemikiran irasional untuk membuat poinnya lebih terlihat oleh klien. d) Memberikan bantuan kepada klien dalam mengevaluasi keyakinan klien tentang pola-pola pikiran logis klien sendiri dan orang lain. e) Membantu klien belajar mengubah keyakinan dan asumsi internalnya. f) Ulangi proses pikiran rasional, kemudian ajarkan klien tentang aspek-aspek penting menggunakan contoh-contoh kehidupan nyata.

\footnotetext{
${ }^{9}$ Erford, Bradley T., 40 Teknik yang Harus Dikuasai., 255.

${ }^{10}$ Erford, Bradley T., 40 Teknik yang Harus Dikuasai., 256.
} 
Bantu klien membentuk tujuan-tujuan yang masuk akal dan bisa dicapai. g) Kombinasikan thought stopping dengan simulasi, PR (pekerjaan rumah), dan relaksasi sampai pola-pola logis benar-benar terbentuk.

Kemudian Beck juga mendorong individu/konseli memahami dan merekonstruksi proses berfikir yang menyimpang, kemudian merubah pikiran-pikiran otomatisnya serta merubah tingkah laku yang menyimpang. Kemudian melatih konseli memahami ide-ide dengan baik serta metode yang sedang dilatihkan untuk mengendalikan pikiran, perasaan dan tingkah lakunya. Pada tahap restrukturisasi kognitif, Beck melakukan hal menarik yaitu: a) Memerintahkan konseli menutup mata, b) Melatih konseli berimajinasi (covert conditioning), dilatih memvisualisasikan dirinya dalam berbagai situasi, baik situasi sebelum maupun setelah permasalahan muncul, c) menyarankan konseli membayangkan dirinya berada pada situasi yang berbeda, bahkan pandangan dari sisi lain yang membantu konseli dalam menyelesaikan masalahnya. ${ }^{11}$

Dapat dilihat bahwa metode-metode yang dikemukakan Beck pada dasarnya untuk melakukan koreksi terhadap pikiranpikiran menyimpang konseli melalui pikiran-piran baru yaitu melalui self-talk dan homework asigment. Sistem kerjanya dengan memberikan sugesti kepada konseli untuk mengasosiasi pikiran-pikiran baru tersebut ke dalam emosi dan perasaannya, setelah proses tersebut dilakukan kemudian konseli ditanyakan kondisi perasaannya setalah mendapatkan sugensti pikiranpikiran positif. Secara naluriah setiap individu akan merasa mendapatkan suatu yang baru dalam hidupnya dan terasa lebih segar dalam situasi emosi dan psikologisnya.

Secara spesifik proses restrukturisasi kognitif yang dilakukan oleh Beck menyerupai proses hipnosis, dengan metode menutup mata konseli, kemudian memerintahkan membayangkan sesuatu sesuai arahan konselor, namun pada proses ini konseli berada dalam kesadaran utuh dan sepenuhnya mendengar suara di sekitar, bahkan konseli dapat merasakan kejadian di sekelilingnya. Sebagaimana disebutkan bahwa dalam proses hipnosis, konseli berada dalam kondisi kesadaran (state of consciousness) bukan kondisi tidak sadar dan para ahli lebih senang menyebutnya dengan istilah alam bawah sadar.

${ }^{11}$ Aladin, Assen, Cognitive Hypnotherapy: An Integrated Approach to the Treatment of Emotional Disorders (London: John Wiley \& Sons Ltd, 2008), 65. 
Secara umum metode hipnosis dimaksudkan untuk menurunkan gelombang otak dari betha menjadi alpha atau theta, dan metode hipnosis aka memudahkan konseli menerima saran atau informasi. Sehingga dalam posisi alpha dan betha tersebut dimanfaatkan oleh konselor untuk mengeksplorasi struktur kognitif konseli yang tersimpan di alam bawah sadarnya, kemudian direstrukturasi menjadi struktur kognitif yang lebih baik (rasional).

Hofman dan Asmundson, mendiskusikan bagaimana teknik cognitive retsructuring membantu konselor profesional mengenal secara kolaboratif pikiran-pikiran irasional atau maladaptif menggunakan strategi-strategi tertentu, seperti logical disputation, Socratic questioning, dan eksperimen prilaku, untuk menantang realitas semula (konseli). Meichenbaum mendeskripsikan tiga tujuan teknik cognitive restructuring yang dapat dipenuhi konselor profesional dan klien sambil menjalani ketujuh langkah yang dideskripsikan oleh Doyle, di atas: ${ }^{12}$

1) Klien menyadari pikiran-pikirannya

Dalam melakukan ini Meichenbaum merekomendasikan untuk menanyakan hal-hal yang berkaitan langsung dengan pikiran dan perasaan klien. Konselor juga dapat membantu klien menggunakan Imagery reconstruction untuk mengakses pikiranpikiran tertentu. Proses tersebut melibatkan klien membayangkan sebuah situasi dalam gerak lambat dan sedemikian rupa sehingga klien dapat mendeskripsikan pikiran-pikiran dan perasaan di seputar insiden tersebut. Lebih mudah lagi jika konselor meminta klien memberikan nasihat kepada seseorang yang mengalami stres akibat situasi serupa seperti yang dialaminya. Meichenbaum juga merekomendasikan supaya klien mencatat pikiranpikirannya melalui self-monitoring (memantau diri sendiri). Kemudian setiap klien terganggu, klien harus mendeskripsikan dalam sebuah catatan harian tentang insiden tersebut beserta pikiran dan perasaan apapun yang dialami.

\footnotetext{
${ }^{12}$ Erford, Bradley T., 40 Teknik yang Harus Dikuasai., 256.
} 
2) Klien merubah proses berpikirnya

Konselor membantu klien mengubah pola pikir dan menumbuhkan kesadaran pada perubahan-perubahan pikirannya, membantu kilen "mengevaluasi pikiran dan keyakinannya, memunculkan prediksi, mengeksplorasi alternatif, dan mempertanyakan logika yang keliru". Dalam mengevaluasi pikiran dan keyakinan klian, konselor dapat mengajukan pertanyaan yang membantu klien mendefinisikan label-lebel yang diberikan sendiri, dengan memerintahkan klien membuat prediksi, konselor membantu klien menyadari pikiran yang rasional dan yang self-defeating. Adapun tujuan dari eksplorasi alternatif untuk mengarahkan klien supaya mengambil perspektif berbeda. Jika klien dapat memunculkan alternatif yang rasional, tidak self-defeating, berarti kemajuan sedang dibuat.

3) Eksperimen klien untuk mengeksplorasi dan mengubah ide tentang dirinya dan dunia.

Jika kondisi klien sudah sipa dan memungkinkan untuk dilakukan pengembangan yang lebih maka konselor memerintahkan klien melakukan eksperimen pribadi dalam ranah terapeutik kemudian beralih pada situasi kehidupan nyata dan dengan metode scheme diary sehingga dapat membantu percepatan proses mengubah keyakian-keyakinan klien. Selanjutnya pembahasan terkait tahapan dalam pelaksanaan teknik cognitive restructuring, Dobson \& Dobson menguraikan tahapan implementasi restrukturisasi kognitif ke dalam beberapa tahapan, diantaranya adalah: ${ }^{13}$

Tahap pertama: Assesmen dan Diagnosa, pada tahap awal tersebut bertujuan memperoleh data tentang kondisi konseli yang akan ditangani serta mengantisipasi kemungkinan kesalahan penanganan selama proses konseling. Dalam tahap pertama dilakukan kegiatan-kegiatan sebagai berikut: a) Penyebaran alat ukur untuk mengumpulkan informasi. b) Melakukan kontrak konseling supaya konseli dapat berkomitmen untuk mengikuti proses konseling dari tahap awal sampai tahap akhir.

${ }^{13}$ Apriyanti, Seli, "Teknik Restrukturasi Kognitif untuk Mereduksi Kecemasan Komunikasi pada Remaja: Penelitian Pra-Eksperimen Terhadap Peserta Didik Kelas X Pasundan Bandung ", Jurnal, (Bandung: repository,UPI, 2014). 
Tahap kedua: Mengidentifikasi pikiran-pikiran negatif remaja, sebelum konseli diberikan bantuan untuk mengubah pikiran-pikiran yang mengalami disfungsi, pertama konselor perlu membantu konseli untuk menyadari disfungsi pikiranpikirannya kemudian perintahkan untuk memberitahukan secara langsung kepada konselor. Pada level umum, konseli didorong untuk kembali pada pengalaman dan melakukan introspeksi atau merefleksikan pengalaman-pengalaman yang sudah dilalui.

Tahap ketiga: Memonitor Pikiran-Pikiran Remaja melalui Thought Record, pada tahap ini konseli diminta membawa buku catatan kecil untuk menuliskan tugas pekerjaan rumah, hal-hal yang berhubungan dengan perlakuan dalam konseling, serta mencatat pikiran- pikiran negatif. Berikut adalah format Thought Record (Rekaman Pikiran) yang diajukan untuk mencatat pikiran-pikiran negatif konseli. Adapun bentuk rekaman pikiran adalaha sebagai berikut:

\begin{tabular}{|c|c|c|c|}
\hline Situasi & $\begin{array}{c}\text { Pikiran } \\
\text { yang } \\
\text { muncul }\end{array}$ & $\begin{array}{c}\text { Emosi (diberi } \\
\text { tngkat intenitas } \\
\text { 100) }\end{array}$ & $\begin{array}{c}\text { Tindakan } \\
\text { yang } \\
\text { dilakukan }\end{array}$ \\
\hline & & & \\
\hline & & & \\
\hline
\end{tabular}

Format dapat dibuat oleh konseli atau disiapkan konselor, format dapat dimodifikasi sesuai kebutuhan karena yang terpenting bukan terletak pada format rekaman pikiran akan tetapi pada isi informasi yang terdapat dalam format. Melalui format rekaman pikiran yang disepakati, konseli harus menjadi partisipan yang aktif dalam memutuskan cara-cara merekam informasi, sehingga dapat berguna dan dapat meningkatkan efektivitas pengerjaan pekerjaan rumah.

Tahap keempat: Intervensi Pikiran-Pikiran Negatif Remaja menjadi Pikiran-Pikiran yang Positif, pada tahap tersebut pikiran-pikiran negatif konseli yang telah terkumpul dalam thought record dimodifikasi. Beberapa hal mengenai pikiranpikiran negatif meliputi: a) Menemukan pikiran-pikiran negatif yang berhubungan denganreaksi emosi yangkuat. b) Menemukan pikiran-pikiran yang berkaitan dengan pola respon perilaku yangkuat. c) Menemukan pikiran-pikiran yang memiliki tingkatan keyakinan yang tinggi. d) Menemukan pikiran-pikiran yang berulang, karena pikiran-pikiran yang dikemukakan berulang-ulang menunjukkan pola berpikir konseli. 
Adapun beberapa penelitian atau kajian terkait implementasi teknik Cobnitive Restructuring beserta efektifitas atau signifikansi teknik tersebut terhadap keberhasilan layanan konseling. Adapun penelitian tersebut antara lain: Pertama: Berdasarkan hasil penelitian Krisnayana, dkk, terkait implikasi teknik restrukturasi kognitf terhadap tingkat resiliensi siswa, dijelaskan bahwa penerapan konseling kognitif dengan teknik restrukturisasi kognitif dapat meningkatkan rendahnya resiliensi 4 orang siswa di XI IPA 1 SMA Negeri 3 Singaraja. Hal tersebut terlihat dari peningkatan resiliensi yaitu dari skor rata-rata 92,5 (resiliensi rendah) menjadi 152,25 (resiliensi tinggi) pada siklus I dan mengalami peningkatan pada siklus II dengan skor rata-rata 161,65 (resiliensi sangat tinggi). Keempat siswa yang mengikuti konseling telah menunjukkan skor resiliensi $\geq 160$, data tersebut berarti bahwa semakin baik konseling kognitif dengan teknik restrukturisasi kognitif digunakan dalam meningkatkan resiliensi, maka akan semakin baik hasil yang didapatkan. ${ }^{14}$

Kedua: Hasil perhitungan data sebelum dan sesudah dilaksanakan treatment teknik cognitive restructuring pada kelompok eksperimen A, teknik thought stopping pada kelompok eksperimen B, dan data kelompok kontrol disajikan dalam tabel 1, dibandingkan dengan data pretest, tampak pada tabel 1, kelompok dengan treatmen cognitive restructuring dan thought stopping mengalami penurunan perilaku bullying pada saat pengukuran posttest, sedangkan pada kelompok kontrol cenderung stabil tingkat bullying-nya pada saat pre dan posttes. ${ }^{15}$

Ketiga: Hasil penelitian menunjukkan bahwa nilai ratarata skor depresi sebelum dilakukan terapi kognitif sebesar 33,59, setelah diberikan terapi kognitif: restrukturisasi kognitif satu kali menurun menjadi 31,24 , dan setelah diberikan terapi kognitif: restrukturisasi kognitif dua kali menurun kembali menjadi 25,97. Penderita depresi perlu melakukan terapi secara tepat dan cepat untuk menghindari konsekuensi bila tidak mencapai kesembuhan. Konsekuensi yang dimaksud yaitu: kendala psikososial

${ }^{14}$ Krisnayana, Ni Nengah Madri Antari, Nyoman Dantes, "Penerapan Konseling Kognitif dengan Teknik Restrukturasi Kognitif untuk Meningkatkan Resiliensi Siswa XI IPA SMA Negeri 3 Singaraja”, Jurnal, Singaraja: ejournal.undiksa, Vol. 2, No. 1, tahun 2014.

15 Futria, Silvia, "Teknik Cognitive Restructuring dan Thought Stopping dalam Konseling untuk Mengurangi Prilaku Bullying Siswa, Jurnal, Prodi Bimbingan Konseling, Pascasarjana, Universitas Negeri Semarang, Vol. 6, No. 1, Juni 2017. 
berkepanjangan, memperburuk prognosis, menambah beban pelayanan medis, meningkatnya risiko bunuh diri dan penyalahgunaan zat, serta meningkatnya risiko kekambuhan. ${ }^{16}$

Keempat: Menurut Davidson, pasien depresi merupakan objek dasar yang disasar oleh teori kognitif, yaitu kesalahankesalahan khusus dalam isi dan bentuk pikiran tertekan yang menunjukkan suatu penyimpangan umum yang negatif dalam berpikir. Adapun tujuan terapi depresi adalah meningkatkan kualitas hidup, mengurangi atau menghilangkan gejala, mengembalikan peran dan fungsi, mengurangi risiko kekambuhan, serta mengurangi resiko kecacatan atau kematian. ${ }^{17}$

Kelima: Berdasarkan hasil penelitian Runia Hanifah, dkk., menunjukkan bahwa Cognitive Restructuing Form (CRF) mampu merubah (terbalik) konsep berpikir dengan mengisi form positive dari perilakunya sesuai dengan yang klien tuliskan. Pada kolom pertama, klien tidak mengisi kolom self talk positif karena persentase kecemasan pada kolom ini dijadikan sebagai baseline, namun untuk beberapa minggu setelah itu klien mampu membuat pikiran alternatif positif terhadap kejadian tersebut. Setelah dilakukan intervensi menggunakan $C R F$, klien lebih mampu menerima kondisi sekitar dan tidak berpikir negatif tentang dirinya sendiri. Kemudian klien dapat membedakan antara yang tergolong self talk negative dan mengubahnya menjadi self talk positive. Intervensi dilakukan dalam waktu dua minggu, ketika klien telah mengerjakan CRF, kemudian mendiskusikannya. Berdasarkan pernyataan klian bahwa setelah membuat kolom pikirannya menjadi lebih terbuka dan mampu berpikir suatu yang lebih positif, dan klien tidak mudah menyimpulkan bahwa yang terjadi merupakan kesalahannya atau citra dirinya yang buruk di mata orang lain dan klien dapat berpikir lebih rasional serta tidak mengambil kesimpulan tergesa-gesa. ${ }^{18}$

16 Wening Marsudi Astuti, Made Sumarwati, Tulus Seyono, "Pengaruh Terapi Kognitif Terhadap Penurunan Skor Depresi pada Pasien Gangguan Jiwa”, Jurnal, Banyumas: The Soedirman Jurnal of Nursing, 2010, Vol. 5, No. 3, tahun 2010.

17 Sitepu, Tanggulangi Depresi Secara Tepat, Artikel (http://dredyputrasitepu.com), Januari, 2008.

Runia Hanifah, Meilanny Budiarti Santoso, "Cognitive Restructuring dan Deep Breathing untuk Pengendalian Kecemsan pada Penderita Fobia Sosial”, Jurnal, Social Wwork Jurnal, ISSN: 2339-0042 (p), Vol. 6, No. 2, tahun 2016, 154-272. 


\section{Penutup}

Berdasarkan penjelasan di atas dapat dilihat bahwa teknik-teknik layanan konseling terus mengalami perubahan, pembaharuan, dan perbaikan dalam memunculkan model-model pendekatan penyelesaian permasalahan individu. Pembaharuan dari teknik Rational Emotive Behavioral Therapy ke teknik Cognitive Restructuring dapat disebut sebagai pembaharuan yang bersifat deduktif sebab dari REBT yang cakupannya lebih umum (REBT) berubah menjadi CR yang cakupannya lebih spesifik (CR). Setiap pembaharuan tentu didasari oleh persoalan tertentu sehingga lahirnya teknik baru merupakan bagian dari upaya perbaikan dari teknik layanan sebelumnya, dan teknik yang baru tentu adalah model layanan yang dianggap lebih efektif dan efisien sebagai penyelesaian permasalahan individu. 


\section{Daftar Pustaka}

Aladin, Assen, Cognitive Hypnotherapy: An Integrated Approach to the Treatment of Emotional Disorders, London: John Wiley \& Sons Ltd, 2008.

Apriyanti, Seli, Teknik Restrukturasi Kognitif untuk Mereduksi Kecemasan Komunikasi pada Remaja: Penelitian PraEksperimen Terhadap Peserta Didik Kelas X Pasundan Bandung, Jurnal, Bandung: repository,upi, 2014.

Astuti, Wening Marsudi, Made Sumarwati, Tulus Seyono, Pengaruh Terapi Kognitif Terhadap Penurunan Skor Depresi pada Pasien Gangguan Jiwa, Jurnal, Banyumas: The Soedirman Jurnal of Nursing, 2010), Vol. 5, No. 3, tahun 2010.

Beck, Judith S, Cognitive Behavioral Therapy: Basic and Beyond (2nd ed). (translite), New York: The Guilfard Press, 2011.

Erford, Bradley T, Teknik yang Harus Diketahui Setiap Konselor, Yogyakara: Pustaka Pelajar, 2015.

Futria, Silvia, Teknik Cognitive Restructuring dan Thought Stopping dalam Konseling untuk Mengurangi Prilaku Bullying Siswa, Jurnal, Prodi Bimbingan Konseling, Pascasarjana, Universitas Negeri Semarang, Vol. 6, No. 1, Juni 2017.

Hanifah, Runia, Meilanny Budiarti Santoso, Cognitive Restructuring dan Deep Breathing untuk Pengendalian Kecemsan pada Penderita Fobia Sosial, Jurnal, Social Wwork Jurnal, ISSN: 2339-0042 (p), Vol. 6, No. 2, tahun 2016.

Jarvis, Matt, Teori-Teori Psikologi: Pendekatan Modern Untuk Memahami Perilaku, Perasaan, Pikirannya Manusia. Bandung: Nusa Media, 2006.

Jones, Nelson, Heory and Practice of Counseling and Therapy, Terjemahan Helly Prajitno \& Sri Mulyani, Jakarta: Pustaka Pelajar, 2012.

Joseph, Gerry Martin and Pear, Modifikasi Prilaku: Makna dan Penerapanya, Yogyakarta: Pustaka Pelajar, 2015.

Komalasari, Gantina, Eka Wahyuni, Karsih, Teori dan Teknik Konseling. Jakarta: PT. Indeks, 2011.

Krisnayana, Ni Nengah Madri Antari, Nyoman Dantes. Penerapan Konseling Kognitif dengan Teknik Restrukturasi Kognitif untuk Meningkatkan Resiliensi Siswa XI IPA SMA Negeri 3 Singaraja, Jurnal, Singaraja: ejournal.undiksa, Vol. 2, No. 1, tahun 2014.

Oemarjoedi, A. Kasandra, Pendekatan Cognitive Behavior Dalam Terapi. Jakarta: Kreativ Media, 2003.

Sitepu, Tanggulangi Depresi Secara Tepat, Artikel (http://dredyputrasitepu.com), Januari, 2008. 